\title{
Developing Critical Reflection: Role of Sustainability in Modern Design and Cultural Heritage
}

\author{
Ramin Dorri* \\ Politecnico di Milano
}

\begin{abstract}
Where the past meets the future is what we call it heritage. Design and cultural heritage are two inseparable elements that are playing an important role in the lifestyle of societies among the time. In other words, they are shaping human activities. In this paper by presenting a case study as an example the aim is to see the design from a new perspective. these days we are becoming more conscious; the sustainability shift leads to a new way of thinking in all levels of society. Sustainable thinking means to design and produce better. Designer's responsibility is to understand the whole design and production process, to recognize how things can be designed to make them easier to recycle and what is their impact on environment. Even though we cannot predict the future now, thinking sustainable is here to stay.
\end{abstract}

Keywords: Design, Cultural Heritage, Sustainability, Modern Design, Production, Environment. 


\section{Introduction}

Milano, an open book of design, where you can perfectly see the heritage of the past, what makes you ask yourself, what will be our heritage for the future? But for me, Milano whisper loneliness, for the last 18 months I have been living alone. My spirit surrounded by a huge space around it. How can I fill it? This is what I often ask myself.

Modern designs of our time, which we will leave for the future as our heritage, are so huge that one must group them. With no doubt design of the past whether -Roman, Romanesque, Gothic, Renaissance, etc. - will always be used as a touchstone for the design of the future, if it is transformed, that is transvalued. But the question is, how do we measure the worth of a heritage? ${ }^{1}$

Modernism launch the principles of design into a new adventure, generally based on the idea - Form follows the Function -. According to modern design, often the space between two volumes is as important as the volumes themselves. The importance is how these shapes are related to each other. In each design, the designer has a very simple problem of a good relationship between volumes and the space. He puts the volumes so that the space between them is about the best he can achieve. They all have that in common. Even in design process of a single piece of furniture, the principle is the same. Only the space between them would be smaller. It is important which shapes we use to make our volumes because they are shaping the space around them; and that is what perhaps we call it our heritage for the future. ${ }^{2}$

Picasso said, 'What do you think an artist is? An imbecile who only has eyes, if he is a painter, or ears if he is a musician, or even if he is a boxer, just his muscles? Far from it: at the same time, he is also a political being, constantly aware of the heartbreaking, passionate, or delightful things that happen in the world, shaping himself completely in their image. Painting is not done to decorate an apartment, it is an instrument of war (Fig). The artist is a receptacle for emotions that come from all over the place: from the sky, from the earth, from a scrap of paper, from passing shape, from spider's web; or, what I 
call it from the empty space around us! The painter goes through states of fullness and evacuation. That is the whole secret of art. A painter paints to unload himself of feelings and visions. Like a designer who is creating deep cheap seats hold its own sweetness in victory. It is not what the artist does that count. But what he is... what interests us is the anxiety of Cézanne, the teaching of Cézanne, the anguish of Van Gogh, or how Nietzsche is calling it the inner drama of the man'. ${ }^{3}$

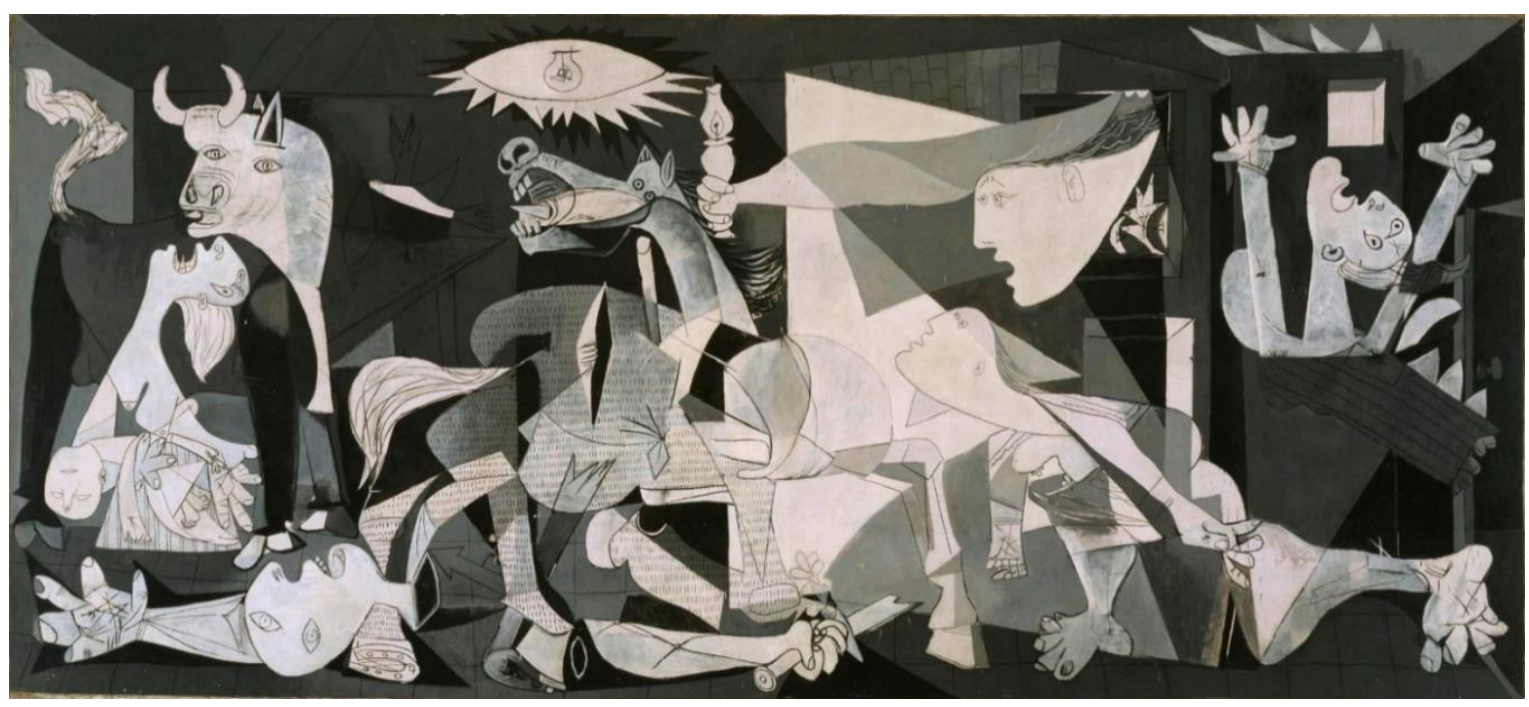

Fig. 1. Guernica, Picasso, 1937. Pinterest.

\section{Case study}

I want to point out here the modular chair collection by Thai design studio Kaoi (Fig. 2) that the designers tried to challenge the geometric lines that define the Memphis movement founded by the Italian designer Ettore Sottsass; the four graphic armrests that can be mixed and matched to create different aesthetic Personalities. the armrests - Han, Somma, Franz, and Mujoel - in different forms of squiggles, zigzags, and arcs reminiscent of the confetti-like pattern called Bacterio that Sottsass designed in $1978 .^{4}$ 


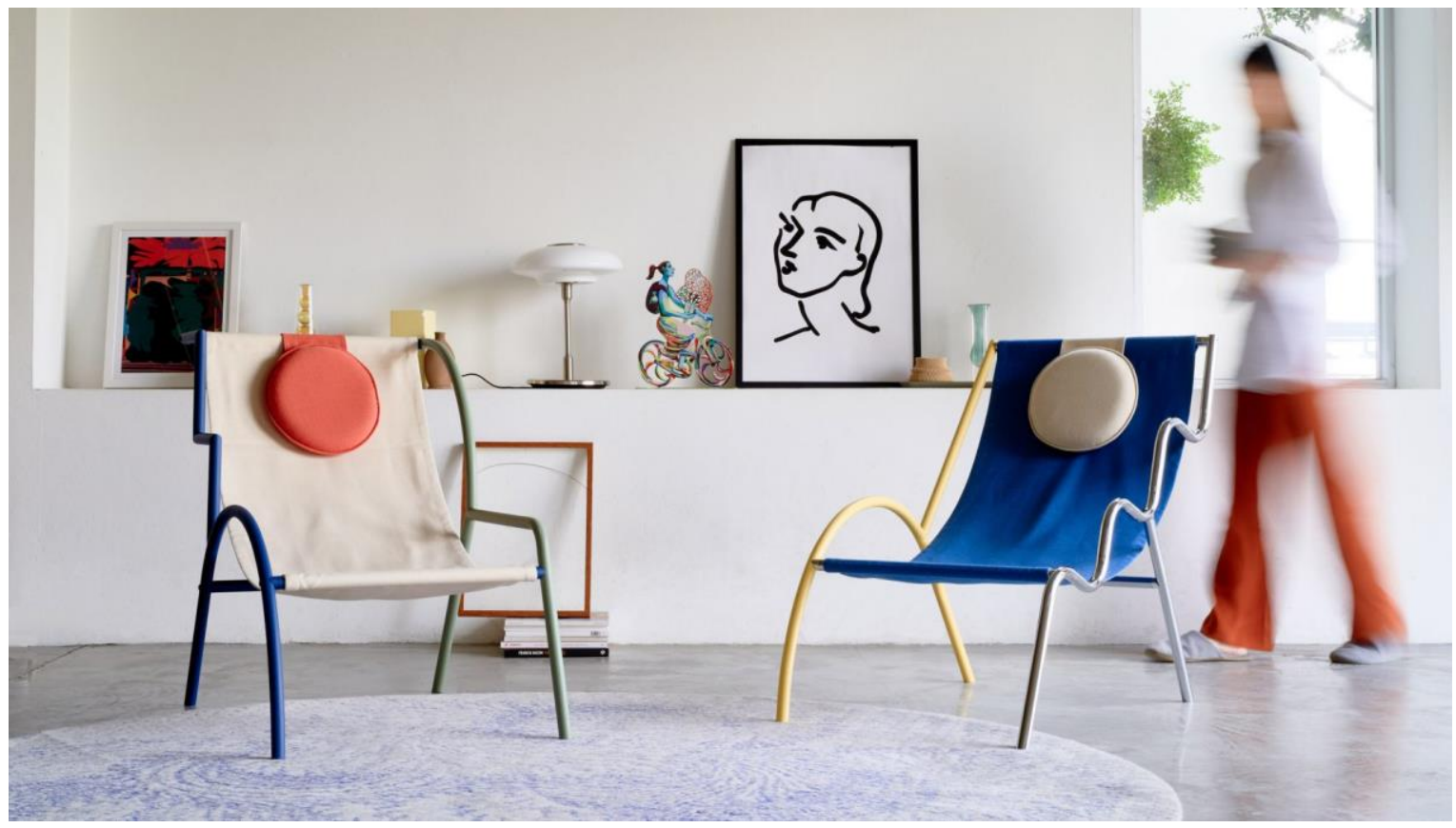

Fig. 2. Kaoi studio, Personality chairs. Thinkkstudio.

Ettore Sottsass intended to define a new approach to design that broke free of the restrictions of functionalism. Each of the individual styles was designed to create various personalities. From gentle, simple lines to super joyful and fun curves. These shapes are paired with vibrant hues including buttercup yellow, midnight indigo, olive green, and shiny chromium. They are trying to shape the space not according to the function, but to the personality of the user who is the actual designer. 'We wanted to create a design that would allow the customer to freely mix and match and recreate their own chair based on their individual personality because we believe that design defines you better than you define yourself' the studio told Dezeen magazine. ${ }^{5}$

When it comes to artistic taste, everything you need as a designer you will have it there. Everyday movements around the house make a choreography that shifts static spaces into a dynamic experience. It is a continuous enhancement rather than to be enforced to arise something new, which is not usually new but literally superimposed. If we start with space, then it will always be typical. Therefore, it would be better to always start from inside to outside. And we have 
to do this with our thinking as well. Designers are critics of civilization, technology and society. ${ }^{6}$

\section{Conclusion}

Having more stuff will make us happier? 'The party is over' said Haugen, who says that designers need to lead the push towards a circular economy. We are experiencing economic and social changes. We have enough stuff; the effort should shift to create something meaningful with less, with recycled materials, to reduce $\mathrm{CO} 2$ emissions, and the design should solve more challenges and develop innovation. Sustainability does not have to mean negotiate; it requests to create objects more meaningful by a responsible choice of materials and processes as today's ongoing culture asks. ${ }^{7}$

Now we are becoming more conscious; the Sustainability shift leads to a new way of thinking in all levels of society. It does not mean to shut down production, but to produce better. Designers should understand the whole supply chain, to recognize how things can be designed to make them easier to recycle. In the manufacturer level, we must be just as persistent on environmental issues. Now we can attend to export the ideas, instead of materials or stuff. Designers can share sustainable methods for a price. Even though we cannot predict the future now, thinking sustainable is here to stay. It is time to find a solution for the future together. By collaborating and using design thoughts we can create our common future. It is today's thought that tomorrow one creates new, and it comes from solitude. Today after 18 months, I am in touch with my spirit, pregnant of solitude that Milano offered me. I am not trying to fulfill it anymore. Without great solitude, no serious work is possible. Without considering the empty space no volume will be designed. Thus, we should pass enough space for the future and not the waste of the volumes we make. Our heritage is leaving the same space and opportunities for the future to create new as much as we have it today (¿Error! No se encuentra el origen de la referencia.). ${ }^{8}$ 


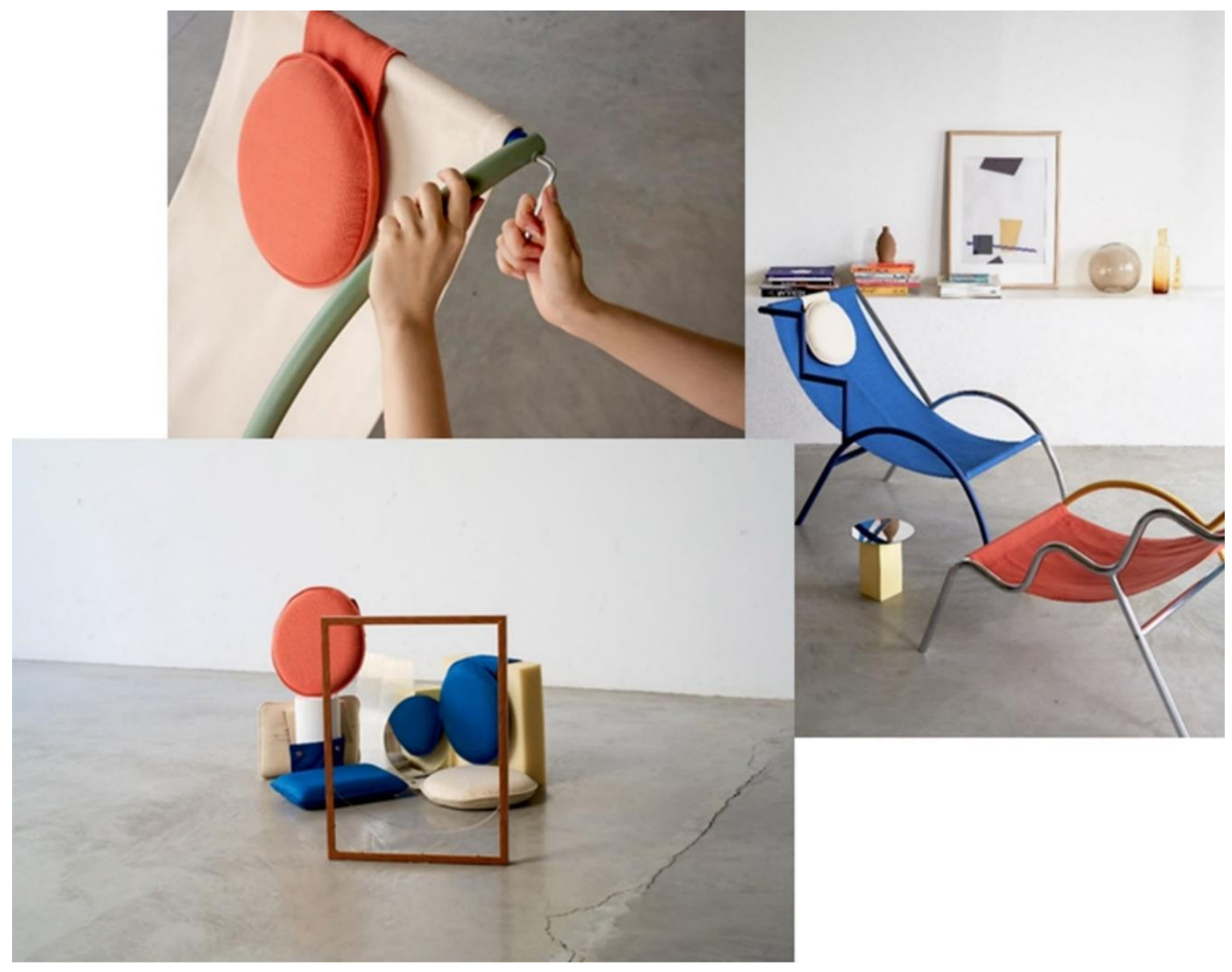

Fig. 3. Kaoi studio, Personality chairs. Thinkkstudio.

\section{NOTES}

\footnotetext{
${ }^{1}$ Vincent A. Masucci, Le Corbusier, Machines for Living: Furniture: a Critical History (Zürich: Centre Le Corbusier Press, 2010). Carter Wiseman, Louis I. Kahn: Beyond Time and Style: a Life in Architecture (London: Norton, 2007).

2 Dominic Bradbury, Modernist Design Complete (London: Thames \& Hudson: 2018). Claire Zimmerman, Mies Van der Rohe 1886-1969: The Structure of Space (Köln: Taschen, 2009).

${ }^{3}$ Simone Téry, "Picasso n'est pas officier dans l'armée française", In Les Lettres Françaises 5, no. 48 (March 24, 1945). Richard Shiff, Cezanne y El Fin del Impresionismo (Chicago: University of Chicago Press, 1986). Vincent Van Gogh, The Letters of Vincent Van Gogh (London: Viking Adult, 1996). Martin Jesinghausen and Douglas Burnham, Nietzsche's 'The Birth of Tragedy' (New York: Continuum, 2010).

${ }^{4}$ Natashah Hitti, "Kaoi studio designs modular Ebba chairs based on Ettore Sottsass' Memphis movement", Dezeen Magazine, accessed May 10, 2020, https://www.dezeen.com/2020/05/10/kaoi-modular-ebba-chairmemphis-group-design/.
} 
${ }^{5}$ Deyan Sudjic, Ettore Sottsass and the Poetry of Things (London: Phaidon Press, 2015). Philippe Thomé, Ettore Sottsass (London: Phaidon Press).

${ }^{6}$ Jason F. McLennan, The Philosophy of Sustainable Design: The Future of Architecture (Kansas City: Ecotone Publishin, 2004). Sian Moxon, Sustainability in Interior Design (London: Laurence King Publishing, 2012).

${ }^{7}$ Sophie Lovell, Dieter Rams: As Little Design as Possible (London: Phaidon Press, 2011).

${ }^{8}$ Amy Frearson, "Norwegian designers point the way towards a circular economy", Dezeen Magazine, accessed April 29, 2020, https://www.dezeen.com/2020/04/29/norwegian-presence-designers-circular-economy/. Stuart Walker, Sustainable by Design (London: Routledge, 2006).

Received: 2020-06-10

Revised: 2020-06-17

Accepted: 2020-09-04 